Animal Health Research Institute,

Assiut Laboratory.

\title{
SOME STUDIES ON BACTERIAL CAUSES ASSOCIATED WITH CASES OF SWOLLEN HEAD SYNDROME IN CHICKENS
}

(With 4 Tables and 14 Figures)

\author{
By \\ FATMA ABDEL MEGID MOUSTAFA
}

(Received at 23/12/2004)

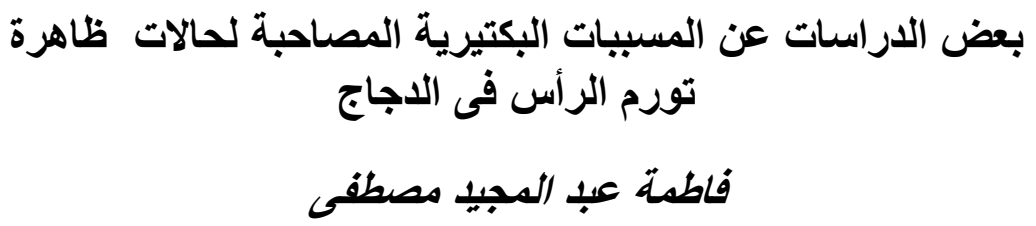

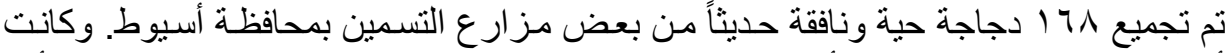

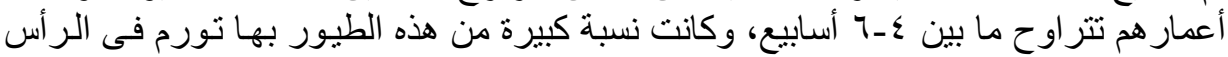

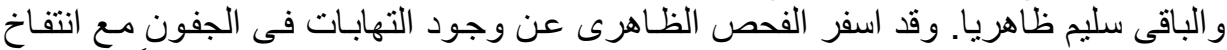

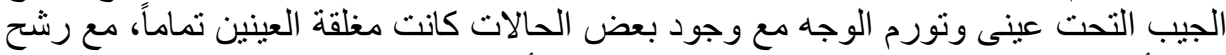

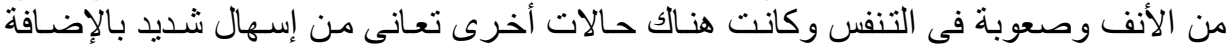

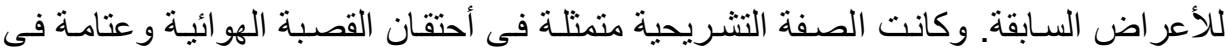

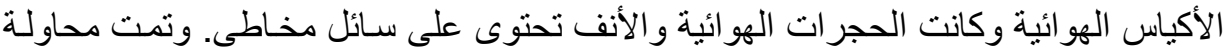

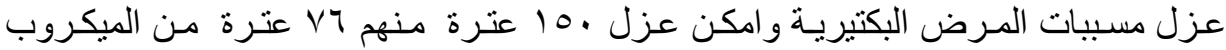

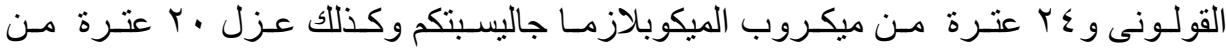

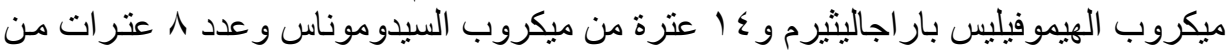

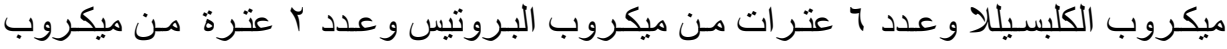

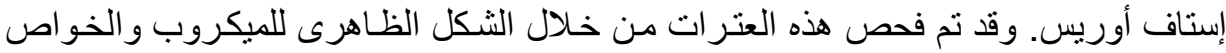

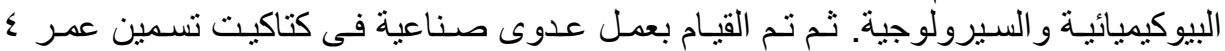

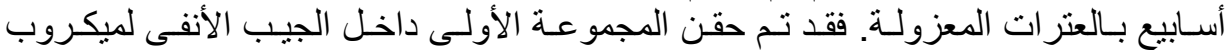

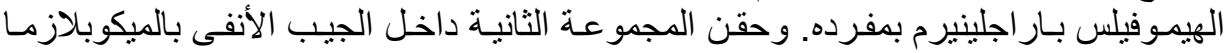

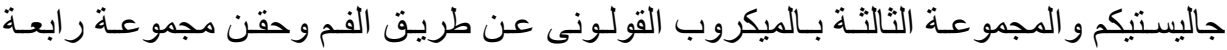

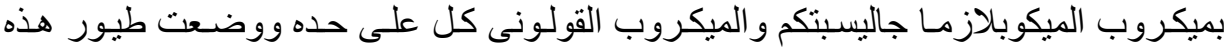

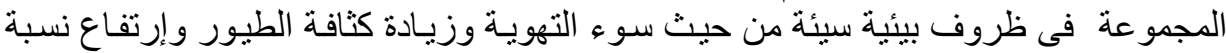

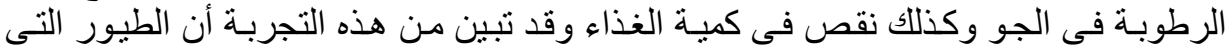

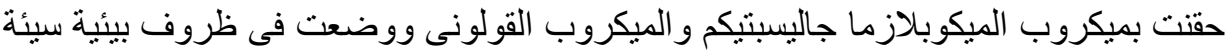

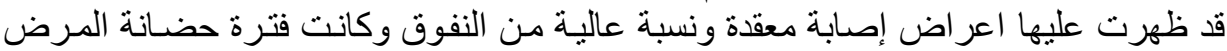

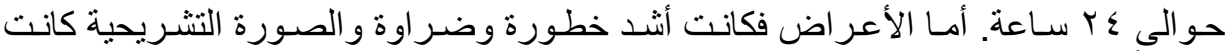

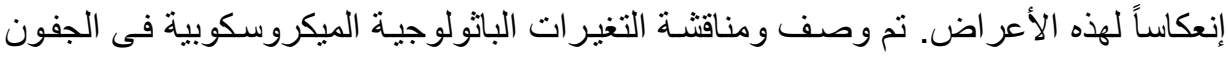




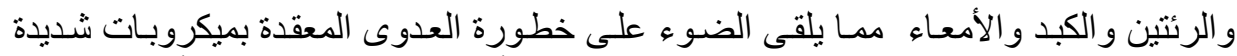

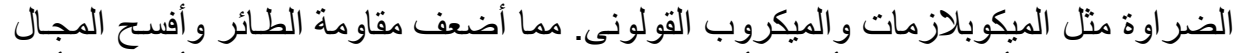

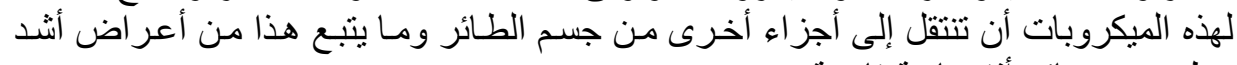
خطورة وخسائر أقتصادية فادحة.

\section{SUMMARY}

One hundred and sixty eight birds were collected from 4 broiler flocks in Assiut farms (governmental and private)from both live and freshly dead birds, aging between 4-6 weeks. The clinical signs showed swelling of heads with conjunctivitis and some birds were with closed eyes, nasal discharge and diarrhea was also noticed in some cases. The causative bacterial agents could isolated only from the sinus and the upper respiratory tract. 150 isolates were recovered from 168 cases, 76 isolates, 24, 20, 14 isolates Pseudomonas aeruginosa, 8 Klebsiella, 6 isolates Proteus, and 2 isolates Staphylococcus aureus. The pathogenicity of E. coli, Mycoplasma gallisepticum and Haemophilus paragallinarum to 4 weeks old broiler birds free from any bacterial infection revealed appearance of depression, conjunctivitis, sneezing, nasal discharge within 3-4 days post inoculation. Injection of birds by Mycoplasma gallispeticum and E. coli in combination with bad hygienic condition, birds showed signs within 24 hours post inoculation in the form of nasal discharge, sneezing, abnormal sounds, facial oedema, swelling in the infraorbital sinuses, conjunctivitis, abnormal ocular secretion and diarrhea. The postmortum of dead cases revealed septicaemia, severe enteritis, perihepatitis, congestion of the lung, air saculitis, sinusitis, tracheitis, pericarditis and caseous material in the nasal passages. Histopathological studies of the chickens experimentally infected with $M$. gallisepticum and E. coli revealed pathognomonic changes in the cutaneous and subcutaneous tissue of periocular skin and eyelids, liver, lung and intestine.

Key words: Swollen head, chickens.

\section{INTRODUCTION}

Swollen head syndrome (SHS) is recently described as an acute respiratory disease observed in two to six weeks old broiler chickens. SHS was first described by Morley and Thomson (1984) who attributed 
the disease to a corona virus with E.coli and the disease seen in broiler chickens between 4 and 6 weeks of age in Southern Africa.

O'Brien (1985) observed a number of broiler parent flocks in East Anglia which shown unusual signs as swollen heads and severe depression. These symptoms are the result of periorbital oedema which is often unilateral. He isolated pure culture of E.coli from the head lesions and meninges. Litjens et al., (1989) reported a case of SHS in guinea fowl and could isolate E.coli and staphylococci during the course of the disease. Treatment of these cases with Baytril produced satisfactory results. Qureshi (1991) recorded the disease in broiler farms in parts of Saudi Arabia and the microbiological examination revealed E.coli in some birds. Arns and Hafez (1992) described the disease in Brazil that it mostly occurs in broilers between 4 and 6 weeks of age. E.coli was isolated from the subcutaneous exudate over the head and from some tracheal swabs. Both Goodwin and Wattman and Droual and Woolcock (1994) investigated cases of SHS and isolated many bacteria as Pseudomonas aeruginosa, E.coli, Proteus, Clostridium and Staphylococcus aureus. Tanaka et al. (1995) stated the first report of an outbreak of SHS occurred in a commercial broiler farm in Miyzaki. E.coli and Proteus mirabilis were isolated from these cases. Georgides et al. (2001) examined 50 commercial flocks in Greece suffering from respiratory disease and signs of swollen head syndrome. The trachea and head were collected from each bird for laboratory investigation. Bacteriological examinations of the affected birds were made from the infraorbital sinuses resulted in the isolation of E.coli, staphylococcus spp. Mycoplasma synoviae and Mycoplasma gallisepticum. They concluded that the TRT virus did not play a causal role in SHS in commercial broiler flocks in Greece but Mycoplasma or other bacteria and environmental conditions seem to be essential for the occurrence and severity of the disease.

Murakami et al. (2002) tested a farm of Japanese quail for egg production, the birds showed swelling head, nasal discharge, increased lacrimation, decreased egg production and mortality rate of $5.7 \%$ per day. They isolated M. gallisepticum, Pasteurella multocida, E.coli, Staphylococcus spp., Streptococcus spp. and Haemophilus paragallinarum (H. paragallinarum). They concluded that the swelling heads in birds due to mixed infection with $M$. gallisepticum and the high level of ammonia fumes promoted infection and multiplication of $M$. gallisepticum. 


\section{MATERIALS and METHODS}

\section{(1) Samples:}

Four broiler farms of 4-6 weeks of age at Assiut governorate were manifested by swelling of the face, eyelids and the head. After 72 hours from the first signs, some birds showed severe oedema of the head and the face with total closure of the eyes and oedema of the tissues in lower jaw and neck. The wattles were swollen only in a small number of birds as well as variable rates of morbidity and mortality. The clinical data concerning these flocks are shown in table (1)

A total of 168 birds with SHS were observed for clinical signs, post mortem and bacteriological examination.

\section{Antisera:}

- E.coli “O”'antisera from Bhring Werk Marburg, Lahn, Germany, were used for serotyping of the isolated strains. The procedure outlined by using polyvalent and monovalent E. coli antisera (Edward and Ewing, 1972).

- Reference M.gallisepticum antisera were kindly supplied by prof. Dr. Adel M. Soliman, Dept. of Poultry Diseases Assiut University.

- Standared strains of H. paragalinarum (Strain 221, Spross and H-18) represnting $\mathrm{H}$. paragalinarum serovars $\mathrm{A}, \mathrm{B}$, and $\mathrm{C}$ respectively were kindly supplied by Dr M. Aly, Prof. of Poultry Diseases, Assiut University.

\section{(2) Isolation of bacterial agent:}

\section{(i) Isolation of $\boldsymbol{H}$. paragallinarum :}

Samples from infraorbital sinuses, exudate from the subcutis of swollen head, trachea, air sac exudates and eye content were collected and cultured on tryptose agar supplemented with $10 \%$ sterile sheep blood with $2.5 \mathrm{mg} / \mathrm{mL}$ reduced form of Nicotinamide Adinine Dinucleotide (NAD) and incubated at $37^{\circ} \mathrm{C}$ under $10 \% \mathrm{CO}_{2}$ tension using candle jar for 24-48 hours.

\section{(ii) Isolation of other bacterial agents:}

Samples were inoculated into nutrient broth at $37^{\circ} \mathrm{C}$ for 24 hours then, streaked on nutrient agar and MacConkey's agar and incubated aerobically at $37^{\circ} \mathrm{C}$ for $24-48$ hours, according to the method of Koneman et al. (1994) and Quinn et al. (1994).

\section{(iii) Isolation of Mycoplasma}

Samples obtained from trachea, air sacs and lung were cultured on brain heart infusion broth at $37^{\circ} \mathrm{C}$ for 3 days then subcultured on 
brain heart infusion agar plates at $37^{\circ} \mathrm{C}$ in moist candle jar under reduced oxygen tension for 7 days, as described by Sabry (1968).

\section{(3) Identification of the isolated organisms:}

\section{Colonial and cellular morphology:}

Colonial morphology were studied and cellular examination from these colonies were done using Gram stain and Indian Ink staining.

\section{Biochemical examination:}

All isolates were subjected to sugar fermentation tests (glucoselactose - mannitol and sucrose). These tests were done according to Cruickshank et al. (1975). Indol production, oxidase test, nitrate reduction test and arginin were carried out according to Cruickshank et al. (1975), Kume et al., 1978; Erno and Stipkovits, 1973.

\section{(4) Serological identification:}

Isolates that produced biochemical reaction simulating $H$. paragallinarum were subjected to serological identification by using rapid plate agglutination test as described by Kume et al., (1978). Isolates that produced biochemical reaction simulating E.coli were serologicoly identified after their purification by determination of the group antigens using slide agglutination test against the E.coli antisera. Isolates that produced biochemical reaction simulating $M$. gallisepticum were serologically identified by growth inhibition test (Clyde, 1964). On the other hand, other organisms either Gram-ve or Gram+ve were identified only by biochemical tests as their respective immune sera were not available.

\section{(5) Pathogenicity test:}

A number of 50 broiler chickens of 4 weeks old were divided into 5 equal groups (10 birds each) and used for testing the pathogenicity of each isolate.

The first group was inoculated via intrasinus route with $0.2 \mathrm{ml}$ of 24 hours broth culture containing $10^{8} \mathrm{CFU} / \mathrm{ml}$ of $H$. paragallinarum (Rimler, 1979).

The second group was inoculated via intrasinus route with 0.1 $\mathrm{ml}$ of 24 hours broth culture containing $10^{8} \mathrm{CFU} / \mathrm{ml}$ M. gallispeticum (Rocke et al. 1988).

The third group was inoculated orally with $0.1 \mathrm{ml}$ of 24 hours broth culture of E.coli (Gross, 1956).

The fourth group was inoculated via intrasinus route with $0.1 \mathrm{ml}$ of 24 hours broth culture containing $10^{8} \mathrm{CFU} / \mathrm{ml}$ M. gallisepticum and 
orally with $0.1 \mathrm{ml}$ of 24 hours broth culture of E.coli and kept under bad hygienic condition (Gross, 1957).

- The fifth group was kept as non infected control.

Birds were observed for 6 weeks for clinical signs and the deaths were recorded. At the end of the 6 weeks the survivors were sacrified and the postmortem lesions were recorded.

\section{(6) Histopathology:}

Representative samples from air sacs, traches, liver, heart, spleen, eyelid were obtained from the group which inoculated with E. coli and Mycoplasma. Samples were fixed in $10 \%$ neutral buffered formalin. The fixed tissue samples were processed routinely for paraffin embedding technique. The embeded tissues were sectioned at 3 um and stained with Haematoxylin and Eosin (HE) (Bancroft and Stevens, 1982).

\section{RESULTS}

\section{Microbiological studies:}

A total of 168 live and freshly dead broiler chickens of 4-6 weeks of ages suspected to be suffering from SHS were obtained from different chickens farms (Table 1) and subjected to clinical, postmortem and bacteriological examination. Cultures from these cases were identified morphologically, biochemically and serologically. Out of 150 isolates, $76(50.7 \%)$ isolates were identified as E.coli. 24 isolates (16\%) were identified as $M$. gallisepticum, 20 isolates $(13.3 \%)$ were identified as $H$. paragallinarum., 14 isolates $(9.3 \%)$ were identified as Pseudomonas, 8 isolates $(5.3 \%)$ were identified as klebsiella, 6 isolates (4\%) were identified as Proteus and 2 isolates (1.3\%) were identified as Staphylococcus spp. are shown in (Table 2).

Thirty one cases out of 168 examined cases were showed mixed infection with more than one type of bacteria. the most prominent organism that share in most cases of SHS was E.coli, but in EL Mabda M. gallisepticum was found in high incidence more than other localities. In Banyzed E.coli and $H$. paragallinarum found in high incidence. In Mangabad found E.coli and M. gallisepticum. Lastly in Bany Hessen Pseudomonas with E.coli the most prominent bacteria. These showed in (Table 3).

\section{The pathogenicity test :}

The pathogenicity test results are shown in (Table 4). In the first group that infected with $H$. paragallinarum, the clinical signs were 
observed 2 days post-infection in the form of nasal discharge, slight swelling of the infraorbital sinuses with reduced food and water consumption.

The second group that infected with $M$. gallisepticum the clinical signs were observed after 3 days post-infection in the form of rales, dyspnea, facial oedema and nasal discharge. Postmortem examination revealed presence of caseous material in the nasal passages, congestion of the lungs and the air sacs were thickened.

The third group that infected with E.coli clinical signs were observed 3 days post-infection in the form of diarrhea, decreased water and food consumption, emaciation and nasal discharge. Postmortem examination revealed congestion and slight swelling of the liver and kidneys, congestion of lungs, pericarditis and enteritis.

The fourth group which was combinedly infected with E.coli and M. gallisepticum. The clinical signs appeared after 24 hours as depression, purulent nasal discharge, abnormal sounds, swelling of the infraorbital sinuses and eyelids with prominent facial oedema, conjunctivitis and diarrhea, emaciation and decreased water and food consumption (Figures 1 and 2).

Dead cases showed septicaemia, airsacculitis which were severe in some cases. Affected air sacs were thickened, opaque and flecked with numerous yellowish white foci, Perihepatitis, peritonitis, tracheitis and pericarditis were also observed.

The fifth group which kept as non infected control showed no clinical signs.

\section{Morphopathological studies:}

Histopathological changes was observed in different organs of experimental birds. However, the most servere changes were seen in the periocular skin and eyelids and the liver of broiler experimentaly infected with $E$. coli and M. gallisepticum.

The pathological changes of the periocular skin and eyelids manifested the followings: edema and necrosis of subcutanous tissue (Fig.3), abscesation in the periocular subcutanous tissue (Fig.4), cellular reaction including macrophage, lymphocyte and heterophilic cells (Fig.5). Thickening of derms and perivascular cuff consists of lymphocyte, somtimes abscesation, esinophilic cells and lymphocyte in cellular reaction (Fig. 6,7) perivascular cuff and thrombosis in blood vessels, the inflammatory process sometimes extend to subcutanous muscular tissue (Fig. 8). Lung showed pneumonia, congestion, cellular 
reaction in septa of alveoli.

Liver showed focal area of inflammation (Fig.9), dilatation of central vein, portal vein and sinusoid which was ingorged with blood (Fig.10). Severe congestion and cellular reaction around central and portal veins (Fig.11). Increase amount of haemosedren pigment and cellular reaction in the liver (Fig.12).

Intestine showed severe inflammatory changes with accumulation of exudate desquamated epithelial cells in the lumen of the intestine (Fig.13) the blood vessels of the cure of the villi is congested and have cellular reaction (Fig.14) .

\section{DISCUSSION}

Swollen head syndrome appears to affect the broiler flocks causing significant losses in many countries. The swelling is the result of oedema and inflammation of periorbital cutaneous and subcutaneous tissue and the swelling extend over the skull. The eyes of the birds closed due to swelling of lacrimal gland and eyelids. So the birds were blind show no desire for food or water and died due to starvation and dehydration.

The objective of the present work is to study the bacterial causes of SHS in broiler flocks which become obvious problem in many farms in Assiut governorate. A number of 168 broiler chickens showing typical SHS from 4 flocks were subjected to clinical, and Post mortem examination. The clinical signs revealed depression, swelling of heads, conjunctivitis, some birds with closed eyes, sneezing, lacrimation, abnormal respiratory sounds and decreased food consumption. Similar finding were observed by Molrey and Thomson (1984), Qureshi (1991), Arne and Hafez (1992) and Droual and Woolcock (1994).

The postmortem findings of examined birds were observed as oedema under the skin of the head region and mild to purulent conjunctivitis, congestion of the trachea, lungs and sinuses. The nasal passages contained frothy mucous with cloudiness of air sacs. These lesions are similar with those reported by Morley and Thomson (1984) and Qureshi (1991) who found beside the above lesions that larynx was contained mucous and food particles and perihepatitis and pericarditis in complicated cases.

Results of isolation indicated that 150 isolates were recovered from broiler chickens. The isolates were identified as E.coli 76 isolates 
(50.7\%), M. gallisepticum 24 isolates (16\%), H. paragallinarum 20 isolates (13.3\%), Pseudomonas aeruginosa 14 isolates (9.3\%) Klebsiella 8 isolates (5.3\%), Proteus 6 isolates (4\%) and Staphylococcus aureus 2 isolates $(1.3 \%)$. These results are in agreement with those reported by Morley and Thomson (1984), Zellen (1988), Qureshi (1991), Aydin et al. (1993), Droual and Woolcock (1994), Cookson \& Shivaprasad HL (1994), Goodwin and Waltman (1994), Georgiades et al. (2001) and Murakami et al. (2002). High incidence of E.coli may be attributed to environmental conditions which play a significant role in interacting with infectious agents in the production of respiratory diseases in poultry (Kleven and Glisson 1997).

Mixed infection showed in 31 cases out of 168 examined cases with more than one type of bacteria. The most prominant bacteria was E.coli which isolated from all cases, this result simillaer with Litjens et al., (1989), Goodwin and Waltman (1994), Tanaka et al. (1995), Murakami et al. (2002).

The pathogenicity tests were designed to reproduce the SHS in broiler chickens using the isolated bacteria. The choice of 4 weeks old broilers is preffered due to the absence of maternal antibodies at this age (Hafez, 1993). The present investigations have confirmed the pathogenicity of $H$. paragallinarum for the experimentally infected birds, the clinical signs appeared at 2 days post intrasinus inoculation. Signs were nasal discharge, slightly swelling in the infraorbital sinuses with decrease food and water consumption, Postmortem examination revealed presence of mucus exudate in the sinuses, congestion of trachea and nasal passages. These observation come in accordance with those observed by Sawata et al. (1985), Aly (1987), Sandoval et al. (1994), Aly et al. (1995) and Blackall (1999).

Regarding the second group which was infected with $M$. gallisepticum, the clinical signs begin at the $3^{\text {rd }}$ day post intrasinus inoculation. These signs were mainly respiratory. These observed signs were similar to those reported by El-Ebeedy (1976). Postmortem findings revealed congestion of lungs, slight turbidity of air sacs, swelling of the infraorbital sinuses and presence of mucous exudate in the trachea. These results are similar to those recorded by Reece et al. (1986) and Cookson and Shivaprasad (1994).

In the third group which was infected with E.coli. The clinical signs appeared after 3 days of oral inoculation. These signs were slightly nasal discharge, ruffled feather, diarrhea, increased body temperature and 
decreased food and water consumption. Postmortem examination revealed congestion and slight swelling of the liver and kidneys. Congestion of the lungs, pericarditis and enteritis. These findings were similar to those reported by Gross (1957) and Gross (1961).

The fourth group which was infected orally with $E$. coli and via intrasinus route with $M$. gallisepticum and kept under bad hygenic conditions such as bad ventillation, over crowdness, mal-nutrition. Showed clinical signs at 24 hours post infection in the form of nasal discharge, sneezing, abnormal sounds, facial oedema, swelling in the infraorbital sinuses, conjunctivitis, abnormal ocular secretion and diarrhea. The examined dead cases revealed septicaemia, severe enteritis, perihepatitis, congestion of the lungs, airsacculitis, sinusitis, tracheitis, pericarditis and caseous material in the nasal passages. These observations were similar to those reported by Gross (1957), Gross (1961), Murakami et al. (2002)who reported that E. coli can not invade the air sacs without $M$. gallisepticum infection .

The histopathological examination showed cellulitis in the cutaneous and subcutaneous tissue of periocular skin and eyelids. The liver showed widence of acute hepatitis with dilatation of the hepatic vasculture indicating toxic chock. The intestine manifest a moderate to severe degree of catarrhal enteritis. These results are similar to those observed by Gross (1957), Tetsuo Nunoya et al (1991) Droual and Woolcock (1994) and Nakamura et al (1997).

From the results of this work we can conclude that the bacterial agents are the main cause of SHS. Management errors act as predisposing causes which influence the appearance of the disease. So it must be emphasized that all aspects of hygiene management especially the ventilation, stocking density, litter condition and general hygiene, should be improved this beside drug therapy with suitable vaccines and vaccination programs should be also used.

\section{REFERENCES}

Aly, M. (1987): Epidemiological and immunological studies on infectious coryza and associated factors with special reference to E.coli. (M.V.Sc.) Thesis, Fac. Vet. Med., Assiut University. Aly, M.; Azhar, M. Adel Aziz and Ashgan, M. Said (1995): Studies on complicated infectious coryza in laying chickens. Alex. Vet. J. 
Arns, C.W. and Hafez, H.M. (1992): Swollen head syndrome in poultry flocks in Brazil. Proceedings of the 4th western poultry disease conference, Sacramento, California, 81: 83.

Aydin, N.; Akan M. and Erdeger, J. (1993): Study on the swollen head syndrome in fowls in the Ankara area. Etlik Veteriner Mikrobiyoloji Dergisi. 7 (4): 34. Cited in Vet. Bulletin. (1994) Vol. 64, No. 8.

Bancroft, D. and Stevens, A. (1982): Theory and practice of histological techniques. 2 Edn. Churchill Livingstone (Edinburgh, London, Melbourne).

Blackall, P.J. (1999): Infectious coryza: over view of the disease and new diagnostic options. Clin Microbiol., 12: 627-632..

Clyde, W.A. (1964): Mycoplasma species identification based upon growth inhibition test by specific antisera. J. Immunology, 92: 958-965.

Cookson, K.C. and Shivaprasad, H.L. (1994): Mycoplasma gallisepticum infection in chukar partridges, pheasants, and peafowl. Avian Dis. 38 (4): 914-921.

Cruickshank, R.; Duguid, J.P. and Swain, R.H. (1975): Med. Microbiol. 12th ed. E.S. Livingstone Limited Edinburgh and London.

Droual, R. and Woolcock, P.R. (1994): Swollen head syndrome associated with E.coli and infectious bronchitis virus in the central valley of California. Avian Pathology, 23: 733-742.

Edwards, P.R. and Ewing, MW. M. (1972): Identification of enterobacteriaceae. 3rd Ed.Burgers publishing co. Minneoplos.

El-Ebeedy, A.A. (1976): Studies on mycoplasma infection of turkeys, ducks and geese. Ph. D. Thesis, Hungarian, Academy of Science.

Erno, H. and Stipkovits, L. (1973): Bovine mycoplasma: culture and biochemical studies. Acta. Vet. Scand., 14: 436-449.

Georgiades G.; Iordanidis, P. and Koumbati, M. (2001): Cases of swollen head syndrome in broiler chickens in Greece. Avian Disease, 45 (3): 745-750.

Goodwin, M.A. and Waltman, W.D. (1994): Clinical and pathological findings inyoung Georgia broiler chickens with oculofacial respiratory disease "So-called swollen heads" Avian Diseases, 38: 376-378. 
Gross, W.B. (1956): Escherichia coli as a complicating factor in chronic respiratory disease of chickens and infectious sinusitis of turkeys. Poult. Sci., 35: 765-771.

Gross, W.B. (1957): Pathological changes of an Escherichia coli infection in chickens and turkeys. Am. J. Vet. Res. 724-730.

Gross, W.B. (1961): The development of "Air Sac Disease". Avian Diseases, 5, 431- 439.

Hafez, H.M. (1993): Pneumovirus infection in turkeys and chickens .proceeding of the 3rd Sci. conference, Egypt Vetrinary Poultry Association. 3- 13.

kleven, S.H. and glisson, J.R. (1997): Multicausal respiratory disease. in diseases of poultry 10 th ed. B. w. calnek, h. john barnes, C. W, beard, 1. R. Mc dougald and Y. M. saif. Iowa state university press, Ames, Iowa. pp. 1008-1009.

Koneman, E.W.; Allen, S.D.; Janda, W.M.; Schrechen-Berger, P.C. and Winn, W.C.C. (1994): Introduction to Diagnostic Microbiology, 4th Ed., J.B. Lippincott Company.

Kume, K.; Sawata, A. and Nakase, Y. (1978): Haemophilus infection in chickens: 1- Characterization of $H$. paragallinarum isolated from chickens affected with coryza. Jpn. J. Vet. Sci. 40 (1): $65-$ 73.

Litjens, J.B.; Willigen, F.C.; Sinke, M. and Kleyn-Van Willagen, F.C. (1989): Swollen head syndrome in a flock of guinea fowl. Eengeval van het dikke-koppen syndroom bijeen. koppel parelhoenders. Tijdschrift Voor Diergeneeskunde 114, 716-720.

Morley, A.J. and Thomson, D.K. (1984): Swollen head syndrome in broiler chickens. Avian Dis., 28: 238-243.

Murakami, S.; Miyama, M.; Ogawa A.; Shimada, J. and Nakana, T. (2002): Occurrence of conjunctivitis, sinusitis and upper region tracheitis in Japanese quail (Cotrunix Cotrunix Japonica), possibly caused by Mycoplasma gallisepticum acompanied by cryptosporidium spp. infection. Avian Path. 31, 363-370.

Nakamura, k.; Mase, M.; Tanimura, N.; yamaguchi, S.; Naka zawa, M. and Yuasa, N. (1997): Swollen head syndrome in broiler chickens in Japan: its pathology, microbiology and biochemistry. Avian Pathol., 26: 139-154.

O'Brien, J.D.P. (1985): Swollen head syndrome in broiler breeders. Vet. Record. 117: 619-620. 
Quinn, P.J.; Carter, M.E.; Markery, B.K. and Carter, G.R. (1994): Clinical Vet. Microbiology. Year Book. Wolfe Publishing Europ Limited.

Qureshi, A.A. (1991): Rhinotracheitis increasing broiler mortality rate. Misset-World Poultry. Vol. 7 No 5: 30-31.

Reece, R.L.; Ireland, L. and Scott, P.C. (1986): Mycoplasmosis racing pigeons. Australian Vet. J., 63 (5): 166-167.

Rimler, R.B. (1979): Studies of the pathogenic avain haemophili. Avian Dis. (23): 1006- 1018.

Rocke, T.E.; Yuill, T.M. and Amundson, T.E. (1988): Experimental mycoplasma gallisepticum infection in Turkeys. J. of Wildlife Disease 24 (3): 528-532.

Sabry, M.Z. (1968): Characterization and classification of avain mycoplasmas. Ph. D. Thesis, Cornell Univ., U.S.A.

Sandoval, V.E., Terzolo, H.R. and Blackall, P.J. (1994): Complicated infectious coryza outbreaks in Argentina. Avian Dis. 38 (3): 672-678.

Sawata, A.; Nakai, T. and Kume, K. (1985): Lesions induced in the respiratory tract of chickens by encapsulated or nonencapsulated variants of $H$. paragallinarum. Am. J. Vet. Res. 46: 1185-1911.

Tanaka, M.; Takuma, H.; Kokumai, N.; Oishi, E.; Obi, T.; Hiramatsu, K. and Shimizu, Y. (1995): Turkey rhinotracheitis virus isolated from broiler chicken with swollen head syndrome in Japan. J. Vet. Med. Sci., 57 (5) 939-941 .

Tetsuo, N.; Masanori, T.; Toshiro, I.; Kinya. T.; Yosaburo, O.; Yoji, N. and Etsuji, H. (1991): Pathology of a broiler disease characterized by the swollen head. J. Vet. Med. Sci. 53(2): 347349.

Zellen, G. (1988): Swollen head syndrome in broiler chickens. Can. Vet. J. 29: 3, 298.

\section{ACKNOWLEDGMENT}

Great thanks to Prof. Dr. A. Z. MAHMOUD Head Department of pathology and clinical pathology faculty of Vet. Med. Assiut University. 


\section{LEGEND OF FIGURES}

Fig. 1: Experimentally infected birds with E.coli and M.gallisepticum show depression and ruffling feathers.

Fig. 2: Experimentally infected birds with E.coli and M.gallisepticum showing facial oedema and swelling of the eylid.

Fig. 3: Eye of infected birds showing edma, necrosis of subcutaneous tissue. H\&E. 10X.

Fig. 4: Eye of infected birds showing wall of chronic abscess in the periocular subcutaneous tissue H\&E. 10X.

Fig. 5: Eye of infected birds showing necrosis of the blood vessels and diffuse heterophil cell reaction in periocular subcutaneous tissue. H\&E. 10X.

Fig. 6: Eye of infected birds showing edema, thrombosis of blood vessels in periocular subcutaneous tissue. H\&E. 10x.

Fig. 7: Eye of infected birds showing cellular reaction of the dermis in periocular subcutaneous tissue. H\&E. 10X.

Fig. 8: Showing extension of inflammation to subcutaneous musscular tissue H\&E. $25 \mathrm{X}$

Fig. 9: Liver of infected birds showing focal hepatitis. H\&E. 10X.

Fig. 10: Liver of infected birds showing inflammatory reaction and dilatation of the hepatic vasculture H\&E. 10X.

Fig. 11: Liver of infected birds showing cellular reaction in the portal area. H\&E. 10X.

Fig. 12: Liver of infected birds showing inflammatory cellular reaction and congestion of the liver. H\&E.10X.

Fig. 13: Intestine of infected birds showing exudate consists of desquamated epithelial cells and inflammatory cells. H\&E. $10 \mathrm{X}$.

Fig. 14: Intestine of infected birds showing hyperemia and thickening of the intestinal villi. H\&E. 10X. 
Table 1: Clinical data of 4 broiler chicken farms in Assiut Governurate.

\begin{tabular}{|l|c|c|c|c|c|c|}
\hline \multirow{2}{*}{ Locality } & \multirow{2}{*}{$\begin{array}{c}\text { No. of } \\
\text { Birds }\end{array}$} & \multirow{2}{*}{$\begin{array}{c}\text { Age } \\
\text { (weeks) }\end{array}$} & \multicolumn{2}{|c|}{ No. of } & Morbidity & \multirow{2}{*}{$\begin{array}{c}\text { Mortality } \\
\%\end{array}$} \\
\cline { 4 - 5 } & & Diseased & Dead & & $\%$ \\
\hline El-Mabda & 150 & 6 & 4 & 10 & 9.3 & 6.7 \\
\hline Banyzed & 100 & 4 & 21 & 7 & 28 & 7 \\
\hline Mangabad & 200 & 6 & 47 & 8 & 27.5 & 4 \\
\hline Bany Hessen & 150 & 5 & 30 & 5 & 23.3 & 3.3 \\
\hline Total & 600 & & 102 & 30 & & \\
\hline
\end{tabular}

Table 2: Recovery rates of different organisms from cases showed SHS.

\begin{tabular}{|l|c|c|c|c|c|c|c|c|c|}
\hline Locality & \multirow{2}{*}{$\begin{array}{c}\text { No. of } \\
\text { examined } \\
\text { cases }\end{array}$} & \multirow{2}{*}{$\begin{array}{c}\text { No. of } \\
\text { isolates }\end{array}$} & & \multicolumn{6}{|c|}{ Bacterial agents } \\
\cline { 5 - 10 } & & E. coli & M. G. & H. para. & Pseudomonas & Proteus & Klebsella & Staph. \\
\hline El-Mabda & 50 & 35 & 15 & 8 & 5 & 3 & - & 4 & - \\
\hline Banyzed & 28 & 24 & 13 & - & 5 & 3 & - & 1 & 2 \\
\hline Mangabad & 55 & 56 & 30 & 11 & 6 & 3 & 4 & 2 & - \\
\hline $\begin{array}{l}\text { Bany } \\
\text { Hessen }\end{array}$ & 35 & 35 & 18 & 5 & 4 & 5 & 2 & 1 & - \\
\hline Total & 168 & 150 & 76 & 24 & 20 & 14 & 6 & 8 & 2 \\
\hline
\end{tabular}

Table 3: Recovery rates of mixed infection :

\begin{tabular}{|l|c|c|c|l|}
\hline Locality & $\begin{array}{c}\text { No.of examined } \\
\text { cases }\end{array}$ & No . of mixed cases & $\%$ & The mixed bacteria \\
\hline G. El-Mabda & 50 & 9 & $18 \%$ & E coli + M .G \\
\hline Banyzed & 28 & 8 & $28.6 \%$ & E .coli + H. para . \\
\hline Mangabad & 55 & 10 & $18.2 \%$ & E . coli + M.G \\
\hline Bany Hessen & 35 & 4 & $11.4 \%$ & E . coli + Pseudomonas \\
\hline Total & 168 & 31 & $18.5 \%$ & \\
\hline
\end{tabular}

Table 4: Results of experimental infection of 4 -week-old chickens with different isolated bacter

\begin{tabular}{|c|l|c|c|c|}
\hline Group & \multicolumn{1}{|c|}{ Infection } & Route & Incubation period & Course of the disease \\
\hline 1 & H. paragallinarum & Intrasinus & 2 days & 10 days \\
\hline 2 & M. gallisepticum & Intrasinus & 3 days & 4 weeks \\
\hline 3 & E. coli & orally & 3 days & 4 weeks \\
\hline 4 & $\begin{array}{l}\text { M. gallisepticum + E. coli in bad } \\
\text { hygienic conditions }\end{array}$ & $\begin{array}{l}\text { Intrasinus } \\
\text { orally }\end{array}$ & $24 \mathrm{~h}$. & 6 weeks \\
\hline
\end{tabular}


Table 4: Results of experimental infection of 4-week-old chickens with different isolated bacteria. 